Fengbin Wang

\title{
The Evolution of Hierarchy toward Heterarchy: A Case Study on Baosteel's Managerial Systems
}

\author{
(C) Higher Education Press and Springer-Verlag 2010
}

\begin{abstract}
In recent years, the hierarchical nature of organizations is severely criticized. Will hierarchy be gradually replaced by networks? Or else, will it be revitalized through certain variations while remaining its distinct characteristics in the vertical relationship between upper and lower levels of an organization? Drawing upon research on "administrative organization" by Simon (1962), this research is based upon an in-depth case study on Baosteel, one of the "Fortune Global 500" Chinese iron \& steel conglomerate. We find that heterarchy is a variation of hierarchy and applicable in both systems of operations management and strategic management. Moreover, the seemingly paradoxical decentralization of authority and concentration of business activities are discovered as the key driving forces in the formation of hierarchical structure. The existence of heterarchy adds variety to organizational world.
\end{abstract}

Keywords hierarchy, heterarchy, vertical specialization

\section{Introduction}

Hierarchy has long been studied in a broad range of disciplines such as sociology, economics and management. Originating in armies and Catholic Churches, the hierarchical form of organization has been diffused into industrial sectors since the Industrial Revolution, dramatically improving productivity. Jaques (1990) argues that managerial hierarchy is a system that allows organizations to make people accountable for getting assigned work done. To govern its internal

Translated from Guanli Shijie 管理世界 (Management World), 2009, (2): 101-122

Fengbin Wang $(\varangle)$

School of Business, Renmin University of China, Beijing 100872, China

E-mail: wfengbin@ruc.edu.cn 
transactions, a hierarchical firm relies heavily on the authority-obedience system to maintain the superior-subordinate relationship along the chain of command (Williamson, 1991, 1996). As Blau and Meyer (1987) points out, authority would push subordinates to accept directives from their supervisors, and thus strengthen organizational coordination and control. In this way, the word "hierarchy" connotes a system of obedience to authority (Milgram, 1974), or a structure of managerial subordinacy (Laurent, 1978; Chandler and Daems, 1980; Radner, 1992).

Nevertheless, the pure hierarchical form has drawn growing criticism from both scholars and practitioners for its disadvantages in terms of transaction or coordination cost, while the networked form, which presents the handshake between invisible and visible hands (Larsson, 1993), shows more advantages over pure market or hierarchy. Thus, the previous bipolar institutional framework of market vs. hierarchy evolves toward a tripolar one with networked form as an intermediate or hybrid one between market and hierarchy (Williamson, 1991, 1996). And along with the notably worldwide success of Japanese firms in the subcontracting of components or subassemblies, a considerable amount of research on networks has been rising in recent years, as if hierarchy is giving its place gradually but inevitably.

However, in the extant literature, much network research focuses on horizontal business relationships (including inter- and intra-organizational transactions) to uncover the movement of market or hierarchy from the extreme polar to the intermediate or hybrid form. Although the horizontal relationship between legally independent firms or internal business units of a firm needs to be explored further, the vertical relationship between upper and lower layers in a managerial hierarchy demands deeper inquiry too. More specifically, in the context of inter-firm relationship, such a vertical relationship refers to the link between outsourcers and 1st-tier subcontractor and further down, between the 1st-tier subcontractor and 2nd-tier subcontractor, and the like; in the context of intra-firm relationship, it generally refers to the connection between supervisors and subordinates, on which this article is targeting.

Unfortunately, whereas the transaction cost theory is powerful to explain the existence of the firm (Coase, 1952; Williamson, 1991, 1996) and the network (Powell, 1990; Larsson, 1993), it seems powerless in the inquiries on the nature of "administrative organization" (Simon, 1997; Cohen, 2007; Jacobides, 2007), which reflects more on vertical specialization, instead of horizontal specialization. Simon (1997) argued that most literatures on organization undervalued the allocation of authorities between supervisors and operators (or subordinators) in composite decision-making processes. Although neo-institutional economists have included micro variables such as governance modes in their studies and tried to differentiate themselves from classic economists, they merely further 
abstracted the similar propositions as the previous economists had done that the firm relies on hierarchy to govern transactions by visible hands (authority) while the market governs transactions by invisible hands (price), thus leaving the focal firm as a "black box" with little consideration for its internal structure.

In this article, we follow Simon (1997) to focus on the vertical specialization between managerial levels and try to answer the questions why the traditional organization of hierarchy needs to vary toward a new model termed as "heterarchy" and what are the key forces driving the variation. After introducing McCulloch's (1965) definition of heterarchy as under the governance of the others, we compare it with hierarchy and (business) networks-The former means under the governance of entrepreneurs as heroes and the latter takes shape through the horizontal specialization between firms or business units. In the detailed case study of a company, Baosteel Group Corporation (hereinafter "Baosteel" for short), we discover distinct structural characteristics of heterarchy and explore the driving forces in its evolution trajectories. By demonstrating the main features of heterarchical-typed organization and explaining the forces driving the evolution of hierarchy toward heterarchy and the reasons of the hierarchy not being replaced by either internal or inter-firm business network, we broaden the current framework of mechanisms of governance to include heterarchy as a new concrete form distinct from both hierarchy and networks. We contribute to the literature dominated by a tripolar (hierarchy-networkmarket) view of organization /governance.

In the next sections, after a brief literature review, methodologies and the chosen case company are introduced. Following an in-depth analysis of the case, we induce several propositions and discuss our findings related to the existing literature, and lastly draw conclusions.

\section{Literature Review}

\subsection{Vertical Specialization vs. Horizontal Specialization}

Organizations are generally treated as complex systems (Simon, 1962; Kast and Rosenzweig, 1979) that can be decomposed into subsystems which, in turn, can be further decomposed into sub-subsystems, and thus producing a multi-layered nestedness. The process of decomposition does not necessarily mean that the nested subsystems have to be homogenous or isomorphic like a Matryoshka. However, in the traditionally hierarchical organization, the same or similar image and function of an upper system is copied at any other lower level. Such an assumption will certainly result in isomorphic dispositions of subsystems across diverse organizational levels, and correspondingly, their subordinate business or production units are forced to become self-contained. 
Simon (1962) suggests that one would expect complex organizations exhibiting a hierarchical structure, and the word "hierarchy" in its narrow meaning as a formal chain of authority is adapted to define the organizational architecture in such a way that each system within an upper-system has a "boss" and a set of "subordinates."

In contrast to hierarchy, the heterarchical-shaped architecture would demonstrate great differences between levels of systems as well as between constituting (sub-)systems, which means that heterogeneous features exist, in the upside view, between the focal organization and its super-system (environment), and meanwhile in the downside view, between the focal organization and its subsystems and further down, between the subsystems and their sub-subsystems.

Simon (1997) portrays the so-called "administrative organization" through an inquiry on decision-making processes which are subject to division of mental labor with the "intended, bounded rationality." To describe the division of decision-making duties between diverse levels of managers, he proposes the concept of vertical specialization which is thought to play a critical role in forming the administrative organization to exhibit a chain-linkage of hierarchical authority. Simon argues that everyone in the organization owns certain authority which permits him $\backslash$ her to make autonomous decisions using his $\backslash$ her expertise and thus influence other members including hislher supervisors. Although his insights into the decomposition and premise control of decision-making processes enhance our understanding on organizational anatomy and organizational physiology, he seems to simplify connections among various decision-making processes in the entire architecture of organization to the so-termed "means-ends chain," leaving the question unanswered: how do a variety of decisions dispersed at different levels and positions link with each other to form a non-hierarchical network nearly unfolded?

Drucker (1973) believes that there are some universal organizing principles. One of them is that "(firms) should decentralize their decision-making authority, and place them on people who are in charge of that action." However, observations and experiences inform him that, in the real business world, firms often forget the truth that it is the front line managers on whom all authority and responsibility center; only what he cannot do himself passes up to higher management. Drucker predicts that, to survive the new economy which is becoming more knowledge-based, organizations should delegate functional responsibility to knowledge workers.

A broad review of the extant literature shows that, while the delegation of authority or decentralization drives a wide distribution of autonomous decision makers in an organization, the functions or responsibilities of managers at diverse levels of managerial chain are still not specified. Recently, social 
network analysis has provided scholars in the field of economic sociology a valuable perspective to analyze the networked form of governance. Yet the concept of network is limited in the narrowly defined business transaction context in which functional specialization between firms or business units is a central issue. While such horizontal type of specialization among "experts" (firms or business units) involved in repeated transactions gives rise to network mode of governance, a vertical type of specialization along managerial levels may make the rebirth of hierarchy possible through the re-configuration of the formerly-termed "chain of command." The following part of literature review on heterarchy convinces that, when the value of the subordinates' autonomy is fully recognized and vertical specialization between levels of management emerges, the variation of the traditional organizational model, hierarchy, is on the way. And the new model, heterarchy, may compete against network as a valuable form of governance in the modern society.

\subsection{Hierarchy vs. Heterarchy}

Hierarchy is widely regarded as a formal organizational structure governed by the legislative and rational authority (Weber, 1978). The neo-institutional economists refer "hierarchy" as an institutional arrangement that regulates transactions within the firm by centralized authority held by the entrepreneurs, while the scholars in management field mostly see hierarchy as a command-and-control system in which the subordinates are submitted to the directives from their supervisors (Laurent, 1978; Ghoshal and Gratton, 2002; Leavitt, 2003; Heckscher, 2007).

A symbolic turning approached in the mid- $20^{\text {th }}$ century, when some scholars criticized traditional views of hierarchy for their dependence upon elites such as entrepreneurs. Based on philosophical thinking, McCulloch (1965) proposes the concept of "heterarchy" which, like hierarchy, originates from Greek. He annexed the prefix "hetero-" (the other, or the alien) with the suffix "-archy" (to rule, to govern...) to create a new word "heterarchy" that means "under the governance of the others", whereas hierarchy that was created by annexing "hiero" (the holy, the sacred) with "-archy" means governing by the heroes. Thus, hierarchy and heterarchy represent two different organizational forms with distinctive governing rules.

Hedlund's (1986) paper on the hypermodern multinational corporations (MNCs ) was the first speculative theoretic achievement on heterarchy, in which he argues that in traditional hierarchies, thinking and action take place at separate locations, and strategy planning (thinking) is restricted within one exclusive 
centre (the brain of a firm) while other peripheral parts in the firm are only implementers. By comparison, in a heterarchy, thinking takes place in the periphery, and it goes together with and directly informs action; thus a heterarchical firm would be a "firm as a brain," and each subsystem of the firm is a "neuron."

Birkinshaw and Morrison (1995) verified Hedlund's theoretical view of heterarchy in the geographically scattered MNCs, where they found that "heterarchy as a unifying concept is very valuable in helping understand the MNC." Their study demonstrates that MNC's structural context varies across different roles of subsidiaries. According to their typology, the "local implementer" is most hierarchy-like in that it is severely constrained by its higher-level commander and just has limited autonomy; the "specialized contributor" has close relations with other subsidiaries in a horizontal coupling business network; and the "world mandate" is most heterarchy-like in that it can "work with the headquarters to develop and implement strategy," and is delegated to integrate worldwide activities (referred to other subsidiaries, this integration means centralization, while referred to the headquarters, it represents decentralization). Obviously, the node in a heterarchical structure, such as "world mandate," is an actor with binary capabilities of thinking and action. And a firm in a heterarchical structure composed of "world mandates" is, according to Birkinshaw and Morrison's (1995) definition, a system of "centralized decentralization."

The above literature on MNCs echoes Simon (1997) and Drucker's (1973) insights into the dispersed decision-making, and demonstrates the existence of multi-agents, i.e., "the firm as a brain" model, while the traditional view of hierarchy regards the firm governed by a single authority centre as "the brain of a firm" (either the entrepreneur of a firm or the headquarters of a MNC). The mutation toward heterarchy has increasingly drawn attentions of scholars in various disciplines; however, a lot of questions are still open. To answer these questions, we pick out a flagship iron \& steel company in China as a sample selected carefully according to the principle of "theoretical sampling" (Eisenhardt and Graebner, 2007) to launch an in-depth case study.

\section{Methods}

\subsection{Research Design}

To trace the evolution path of heterarchy and generalizing propositions on the organizing rules, this article follows a research design suggested by Yin (2004) 
as well as Eisenhardt and Graebner (2007) to choose a typical single case while using sound theories to guide the case study process.

Firstly, since there is little research on heterarchy in the Chinese business settings except for in MNCs, an exploratory study based on field observation and interviews in the sample company will help to clarify what heterarchy really is. More specifically, the what-type of inquiry answers questions as follows: What is the heterarchical form of organization? If it is a kind of vertical network, is it reasonable to regard it as a variation of hierarchy, instead of business network? To what extent does the varied organization model differ from the traditional hierarchy?

Secondly, explanatory research can be made in order to answer the how- and why-type of questions: How did the focal firm's heterarchical form of organization take shape after it stopped implementing rigorously "hierarchical management?" And what are key factors activating its evolution from hierarchy to heterarchy? Is the transverse extension of heterarchical form from MNCs to some independently-operated large-sized domestic companies empirically feasible? And finally, why the mutation of hierarchy toward heterarchy helps firms survive well in spite of various institutional alternatives including market and network?

As to the study of case company, we carry out a cross-contextual comparison after separate descriptions of its operations management and strategic management systems. This is an intentional research design to make up the underlying external validity shortages usually found in a single case study.

\subsection{Research Setting}

Baosteel is the most competitive steel complex in China. The construction of its plants started in 1978, the beginning of China's "Reform and Opening Up" era. In 1988, Baosteel was transformed into a group company. Ten years later, the group company as a state owned enterprise merged with two group companies owned by the local government, i.e., Shanghai Metallurgical Holding Group and Meishan Iron \& Steel Co., to improve status and enhance competitive capabilities in the worldwide steel markets. Through consolidation of internal and external resources to raise its competitiveness, its business structure including main steel business and relatively diversified sectors has preliminarily taken shape.

Focusing on the production of hi-tech and high value-added premium steel, Baosteel's main steel business has reached an annual production capacity around 30 million tons. Its steel industry covers three major categories: carbon steel, stainless steel and specially-alloyed steel, which are widely applied in the sectors of automobile, home appliance, petrochemical, machinery manufacture, energy 
$\&$ transportation, building \& decoration, metal products, aviation and aerospace, nuclear power and electronic instruments, etc. While maintaining its dominance in domestic flat product market, Baosteel's products are also exported to over 40 countries and regions including Japan, South Korea, Europe and America.

In 2008, Baosteel reported a sales revenue of 246.8 billion Yuan, a total profit of 23.8 billion Yuan, a total assets of 352.5 billion Yuan and a net assets of 219.4 billion Yuan. The number of Baosteel's employees has reached 0.1 million.

We select Baosteel as the case sample for the following three reasons. Firstly, it satisfies the requirements of theoretical sampling. Not only its operations management system reflects the non-hierarchical relationship between the operational headquarters and grass-root units, but also the parent-subsidiary relationship between the Group Corporation and its subsidiaries reflect a unique pattern of coupling among levels of management different from the classical hierarchical organizations.

Secondly, with a history of more than thirty years, Baosteel is the largest and most competitive iron and steel conglomerate in China and consecutively stayed in the "Fortune Global 500" in the past six years. Its distinctive management experiences have been widely respected at home and abroad. Making a longitudinal study on this relatively well-known company could enhance the acceptance level of induced theory.

Thirdly, Baosteel shows a unique organizational structure, which seems to be counter-intuitive, thus helps improve the limited "external validity" of a single-case study. Intuitively, enterprises characterized by continuous mass production in the iron and steel industry are expected to rely heavily on the hierarchical, authority-obedience system to guarantee the streamline operations. If a company in this typically "traditional industry" can obtain excellent performance with a non-hierarchical organization model, conclusions inferred from its unique practices could be regarded considerably sound.

\subsection{Data Collection and Clarification}

Data about Baosteel were collected in several stages, in 1990, 1998, 2005 and 2008. The process, initially exploratory, started from a fieldwork in Baoshan Iron $\&$ Steel Federate Plant which was the predecessor of Baosteel in the summer of 1990. The author was a member of a team with a mission to generalize Baosteel's "modern management experiences" and participated in a 45-day-long survey on Baosteel's management practices, and after that, joined follow-up programs on "Learning from Baosteel" in Peking Coking Plant and some other benchmarking plants. Extensive managerial presentations and reports, as well as scheduled open or semi-structured interviews with top managers in charge of enterprise management, directors in the general and specialized management 
departments and representatives from the middle and grass-line managers were organized by the project coordinator in the plant's location, with a result of a serial of books about Baosteel's management published. The second stage of data collection was in the autumn and winter of 1998. The author took up a consulting project, which provided the author good opportunity to frequently contact the chief officials in Baosteel as well as unusual access to its archival materials. Thirdly, at the end of 2005, under the joint effort of the author and a student assistant, the case data was sorted out, codified and updated, with some inclusion of secondary data. Finally, in the summer of 2008, the author classified the historical data intentionally and, at the same time, collected intensively the latest second-hand materials from official websites and other channels, and began to make a systematical comparison between the management practices of Baosteel and other large iron \& steel companies both at home and abroad (including Nippon Steel Co. in Japan and TK Group in German).

Although the multi-sourced data provides triangulation for improving the validity of case study, potential ambiguous or conflicting descriptions tend to exist in the diversified source of data, especially in the various secondary data, and in the different recalls on the firm's historical practices. To eliminate potential false interpretation of the data and, moreover, to identify the unique comparable practices amongst the adjusted descriptions on the firm's evolutionary development, we made careful distinction between historical facts and opinions of the reporters or descriptors. Besides, we intentionally and strictly distinguished management practices at different levels or entities of Baosteel Group, including Baosteel Group Corporation (the parent company), Baoshan Iron \& Steel Co. Ltd. (one of the public-listed subsidiaries with its main assets coming from the formerly Baoshan Iron \& Steel Federate Plant) and other subsidiary companies, factories (i.e., second-level plants), branch factories, and workshops. In the meanwhile, in order to reach a clear and consistent interpretation of the practices, we used such phrases or codes as Descending Center of Management, Delegation of Authority, Decentralization, Dispersed versus Centralized or Integrated Operation of Businesses, Concentration, and other key words to classify related materials and make semantic analysis.

\section{Case Analysis}

Baosteel's managerial systems have evolved for over thirty years. Here we firstly track its operations management system which took shape originally in the production management of iron and steel products in Baoshan Iron \& Steel Federate Plant and later (especially after the merger in 1998) was transplanted into other factories or business units. Then, we turn to its strategic management system adopted to manage the group's diversified businesses. After the separate 
descriptions of the two systems, a cross-contextual comparison is made to extract their shared characteristics, which supplies an empirical foundation for proposition inference in the latter section of this article.

4.1 Baosteel's System of Operation Management: Centralized Functional Management with Comprehensive Integration and Descended Center of Management

Since its establishment in the beginning year of China's Reform and Opening-up, Baosteel has endeavored to build a "modern model" of production management to accommodate its imported Japanese technologies in the processes of iron-making, steelmaking, cogging and so on. After a few years' absorption and adaptation of Nippon's experiences, Baosteel has gradually developed an efficient and flexible managerial system termed hereby as "layered management." The system deviates greatly from the one commonly adopted in China in early 1980s, the latter was characterized by "hierarchical management" in the line sectors and "segmented functional management" in the staff sectors. The comparison between the Baosteel's model traditional model and in operations management is depicted in detail in Table 1. The formation of the "layered management" system includes the following three aspects of organizational changes.

\subsubsection{Empowered Worksite Managers and Descended Center of Operations Management}

While learning from Nippon Steel Co. to install "five mutually-enabled systems" (i.e., worksite-managers, planned figures, standardized operation, selfmanagement, and site facility inspection and maintenance) in the grass-roots units, Baosteel took initiatives to revise them by giving more prominence to "empowered worksite-manager" system rather than "planned figures" (CEC, 2007). The company delegated front-line worksite managers with decisionmaking rights in three areas: 1) operation and personnel management within the worksite; 2) cross-worksite operations management following the principles of procedural obedience; and 3) joint management of the workshops to which the worksite belongs.

Accompanied by the empowerment on worksite managers, the role of higher-level managers including those at the workshop level and above, the factory-and headquarter-level, changed dramatically. No longer acting as commanders to issue orders down to the subordinates, the heads of the workshops and factories became leaders like advisers or coachers, while worksite managers turned to play decisive roles in operating the production lines. In 
Table 1 Comparison between Traditional Enterprises and Baosteel in the System of Operations Management

\begin{tabular}{|c|c|c|}
\hline & $\begin{array}{l}\text { Scale-based "hierarchical } \\
\text { management" in traditional enterprises }\end{array}$ & $\begin{array}{l}\text { "Layered management" with full } \\
\text { delegation of decisions in Baosteel }\end{array}$ \\
\hline $\begin{array}{l}\text { Functional } \\
\text { relations } \\
\text { between } \\
\text { headquarters } \\
\text { and field } \\
\text { units }\end{array}$ & $\begin{array}{l}\text { The headquarters and field units } \\
\text { overlay in functions, the whole } \\
\text { company keeps almost all of the } \\
\text { supporting activities inside, and their } \\
\text { business units are self-contained } \\
\text { either. The supporting functions } \\
\text { extend in all levels, with field units, } \\
\text { workshops and branch factories } \\
\text { allocating nearly the same functional } \\
\text { groups as the headquarters. The } \\
\text { functions in field units are numerous } \\
\text { and jumbled, resulting in } \\
\text { overstaffing of non-productive } \\
\text { personnel and narrow span of } \\
\text { control }\end{array}$ & $\begin{array}{l}\text { The separation of supporting activities } \\
\text { from primary value-adding activities } \\
\text { in the company as well as field units. } \\
\text { Materials supply, facilities } \\
\text { maintenance and other non-core } \\
\text { functions are separated from the main } \\
\text { production units. Functional groups } \\
\text { which used to spread over branch } \\
\text { factories and even workshops are } \\
\text { concentrated to the central } \\
\text { departments, turning the former into } \\
\text { such production units as front lines. } \\
\text { The simplifying operations coupling } \\
\text { with the cutting of functional groups } \\
\text { and staff in all lower levels under the } \\
\text { operation headquarters promotes } \\
\text { broadening span of management, with } \\
\text { the result of a downsized managerial } \\
\text { forces, e.g., just one manager and } \\
\text { another deputy manager in each of } \\
\text { branch factories, and only one } \\
\text { manager in each of workshops }\end{array}$ \\
\hline $\begin{array}{l}\text { Vertical } \\
\text { division of } \\
\text { duties } \\
\text { between the } \\
\text { higher- and } \\
\text { lower-levels } \\
\text { along the } \\
\text { managerial } \\
\text { chain }\end{array}$ & $\begin{array}{l}\text { Top managers are the commanders in } \\
\text { all operational issues, with decision } \\
\text { making authority highly centralized. } \\
\text { Worksite supervisors follow the } \\
\text { directives from the upper levels and } \\
\text { are responsible for the absolute } \\
\text { implementation of these directives; } \\
\text { middle-level managers are just } \\
\text { transmitters of commands from the } \\
\text { above and messages from the grass } \\
\text { fields. The authority structure } \\
\text { appears like a pyramid. Everyone is } \\
\text { busy in "fire fighting" when } \\
\text { incidents occur in the front lines }\end{array}$ & $\begin{array}{l}\text { The center of operations management is } \\
\text { descended down till field units, with } \\
\text { worksite managers acting as } \\
\text { "small-sized factory directors," being } \\
\text { empowered with authority to mobile } \\
\text { other managers in the same rank or } \\
\text { above to co-resolve problems at } \\
\text { worksites, thus become front-line } \\
\text { commanders. The headquarters supply } \\
\text { "through-out integrated" services for } \\
\text { field units. Different type of } \\
\text { responsibilities are definitely assigned } \\
\text { to managers at each level, including } \\
\text { worksite managers, workshop } \\
\text { managers, branch-Factory managers } \\
\text { and those in the functional } \\
\text { departments in the headquarters }\end{array}$ \\
\hline
\end{tabular}

particular, worksite managers were authorized to mobilize other managers in the same rank or above, who were subject to the principles of procedural obedience, to co-resolve on-site problems. In such an arrangement, worksite managers acted like factory directors in small enterprises. As a result, the center of operations management descended from the upper level to the front line.

In an interview with Baosteel's employees, a worksite manager was referred as "a commander in the front line," and what the above-level mangers devolved 
to worksite managers were authority and corresponding responsibility but not accountability. The interviewees informed us consistently that "workshop managers are accountable, without exception, for the decisions delegated to their subordinate worksite managers, thus result in a situation in which the scope of accountability of the workshop managers is actually 'larger' than that of their counterparts in the old-styled enterprises." As a fact, to encourage worksite managers to make delegated decisions independently, a principle to "tolerant the errors in making decisions but not errors in implementing decisions" was insisted. At the one hand, it freed worksite managers from psychological burden by allowing them to make temporally wrong decisions; at the other hand, it served as a measure to cultivate worksite managers' ability via learning by doing, i.e., exerting their authorities dauntlessly.

\subsubsection{Vertical Concentration of Supportive Functions}

To focus the energies of front line managers on value-adding production activities, Baosteel concentrated a wide variety of supporting activities at the operational headquarters. Unlike most Chinese state-owned enterprises which adopted the so-called "hierarchical management" system with two or more managerial levels sharing nearly the same management duties, Baosteel tried hard in its early days to abandon the line's self-contained structure and keep only a few functional departments at lower levels of the firm. For example, the set up of four functional and one secretary departments at second-level factories, which afterwards were completely eliminated, was the first step in designing a leaner functional configuration ranging from workshop or branch factories to second-level plants. After the transition of functional management to a concentrated one, nearly all supportive activities or functions formerly dispersed among the line units were taken over by the operational headquarters.

To illustrate, in the typical "hierarchical management" system, the headquarters were responsible for the yearly or longer-periodical plans, and the factories or workshops downward were, at the same time, responsible for quarterly and monthly operational plans. If there is any difference between the higher and lower levels, it is only in quantity (different scale of the same duty) but scarcely in quality (different duties). In sharp contrast, the Production Department in Baosteel's headquarters takes charge of the overall production management from inflows of raw materials to outflows of products, and makes detailed production plans directly for each individual worksite without any mediating of workshop andlor factory. The same change can be seen in the other functional departments, such as Material Department, Facility Department and Personnel Department. Separating all the supportive functions from primary value-adding activities leaves the line units one pure duty-production, and this kind of vertical specialization has driven the operational headquarters to change 
from the center of command to that of service.

\subsubsection{Horizontal Comprehensive Integration in Staff Departments}

To match the vertical concentration of supportive functions, Baosteel implemented a horizontally "comprehensive integrated" management policy at the operational headquarters. Firstly, related functional departments were merged into a few integrated "compound departments," which simplified the division of labor formerly based on specialization and contributed to the reduction of staff personnel and institutions, and further more, promoted the collaboration among related functions.

Secondly, as a substitute for technological or process specialization, the rule of division based on product specialization was adopted in the "compound departments." Baosteel established, for example, plate steel, tube steel, bar steel and other sub-departments in the Technology \& Quality Department. In contrast, in China's most iron and steel enterprises, staff departments were usually organized in the same way as line departments, which were divided according to different production stages and were merely responsible for parts of the operation. Thus stuff departments usually became isolated technological "silos." But in Baosteel's "compound departments," the central staffs in the headquarters were organized to provide total solutions for the front-line worksites.

Thirdly, in addition to several committees as a regular mechanism for horizontal coordination, Baosteel set up "coordination promotion" offices, which followed the rule of "specialization in general functions and synthesis in throughput processes" to facilitate cross- or within-department collaboration. For instance, in the above mentioned Technology \& Quality Department, the unit named Quality Standard Section was designated as a "coordination-promotion" office to coordinate quality management across and within the department.

Fourthly, a large number of departments in the operational headquarters usually sent their staffs out to the field units to supply near-site services, and these staffs as well as their affiliated departments were subject to the principles of procedural obedience, including those of supporting functions' obedience to primary functions and the upstream stages' obedience to the downstream stages, etc.

4.2 Baosteel's System of Strategic Management in Diversified Businesses: Decentralization of Strategic Decisions to the Consolidated Sub-Group Subsidiaries

\subsubsection{Demand on Effective Group Management}

In the initial stage of its development, the main objective of Baosteel was to set 
up a scientific and efficient production management system and technologically advanced iron \& steel plants. But since Baosteel Group Corporation was originally set up in 1988 and expanded greatly after the merger with other two group companies in 1998, Baosteel has diversified into the iron \& steel related and even non-related businesses. The performance of the whole group, however, was far from satisfaction. According to the statistics, in 1997, the core company in the group created a profit of 1.913 billion Yuan, but in contrast, the other four subsidiaries in the same iron \& steel business made an accumulated deficit of 1.05 million Yuan. Under the joint intervention of the central and local governments, in 1998, Baoshan Iron \& Steel (Group) Corporation absorbed the assets of other two grouped iron \& steel companies-Shanghai Metallurgical Holdings (Group) Corporation and Shanghai Meishan (Group) Co. to establish the Shanghai Baosteel Group Corporation. After the merger, Baosteel Group became the largest iron \& steel group company in China, but this helped little in improving the performance of the expanded group even though its size was scaled up quickly. The acquired affiliates lagged in both technology and management, and to a large extent, subsidiaries that were owned by different "parent companies" competed against each other in the over-congested businesses.

\subsubsection{Emergence of New Strategic Management Model}

Since it was difficult and even impossible to integrate all the acquired companies overnight, Baosteel took measures to lay a path of transformation. The parent company tried hard to transplant the operations management practices of Baoshan Iron \& Steel Co. Ltd., the flagship subsidiary of the group, into the newly-merged subsidiaries including No.1 Steel Company, No.5 Steel Company, Shanghai Meishan Co. and others within the iron and steel industry. And it gradually downsized the members of the whole group from 836 to 450 and cut the chain of property-ownership from six levels to four.

Then Baosteel designed a two-step strategy to build its new architecture of group management. Firstly, in the early stage of the merger, Baosteel adopted a relative-decentralization-oriented policy (even more decentralized than ThyssenKrupp Group headquartered in German). Secondly, based on industry- or product-specialization, Baosteel consolidated the dispersed and competing subsidiaries in the same business sectors or industries respectively into single sub-group companies and delegated the later strategic decision-making authorities in the specific business sectors. Following the grand strategy of "making the dominant business extremely strong and diversifying its related businesses to the appropriate extent," Baosteel took several steps to integrate the operation of its core business, while employing relatively flexible organizational 
forms in non-core businesses to fit the features of each business sectors.

Take the dominant business (i.e., iron and steel) as an example. When a series of strategic adjustments in Shanghai Metallurgical Holdings (Group) Corporation and Shanghai Meishan (Group) Co. were nearly completed, Baosteel Iron \& Steel Co. Ltd held by Baosteel Group Corporation issued additional 5 billion shares in April, 2005 (after it was listed for five years) to conversely purchase the assets of Baosteel Group Corporation so as to consolidate the whole iron and steel business into a single corporation. The departments related to the iron and steel business, including Marketing, Production Management, Engineering, Facilities, and Technology Center, which were originally located in the headquarters of the group corporation, were correspondingly transferred into Baoshan Iron \& Steel Co. Ltd.

After the business consolidation realized firstly in the iron and steel industry and later in other core businesses, the authorities of making growth strategy in each industry were delegated to the designated sub-group companies. Henceforth, the role of Baosteel Group Corporation changed from a mixed business and holding entity to a pure holding company, responsible mainly for the group-level grand strategy and the cultivation and management of major sub-group companies. And Baoshan Iron \& Steel Co. Ltd, in turn, became the sole operational headquarters of the iron and steel business sector.

The evolution path of the diversified business management system within Baosteel, and the new relationships between parent company and major subsidiaries were summarized in Table 2 .

4.3 Cross-Contextual Comparison: Emergence of Heterogeneity in Each Layers of Baosteel Group

The above-described practices of Baosteel indicate that the subsystems nested in a larger system are not necessarily isomorphic just like a "Matryoshka" shown

Table 2 Evolution of Baosteel's Management System in the Course of Diversification

\begin{tabular}{llll}
\hline & $\begin{array}{l}\text { From the foundation of } \\
\text { the group to the eve of } \\
\text { the merger (1988- } \\
\text { 1997) }\end{array}$ & $\begin{array}{l}\text { During the initial } \\
\text { stage of the } \\
\text { merger (1998- } \\
\text { 2004) }\end{array}$ & $\begin{array}{l}\text { During the later stage of the } \\
\text { merger (after 2004/2005 to } \\
\text { present) }\end{array}$ \\
\hline $\begin{array}{l}\text { Grand } \\
\text { strategy of } \\
\text { the group }\end{array}$ & $\begin{array}{l}\text { To form the layout of } \\
\text { "one core business with } \\
\text { diverse businesses" by } \\
\text { separating accessories } \\
\text { from main parts and } \\
\text { taking the initiatives to } \\
\text { diversify }\end{array}$ & $\begin{array}{l}\text { To scale up the } \\
\text { iron and steel } \\
\text { business, } \\
\text { meanwhile } \\
\text { develop } \\
\text { diversified } \\
\text { businesses }\end{array}$ & $\begin{array}{l}\text { To expand and strengthen the } \\
\text { iron and steel business, } \\
\text { meanwhile develop appropri- } \\
\text { ately the related diversified } \\
\text { businesses }\end{array}$ \\
& & & \\
\hline
\end{tabular}


(Continued)

\begin{tabular}{|c|c|c|c|}
\hline & $\begin{array}{l}\text { From the foundation of } \\
\text { the group to the eve of } \\
\text { the merger (1988- } \\
\text { 1997) }\end{array}$ & $\begin{array}{l}\text { During the initial } \\
\text { stage of the } \\
\text { merger (1998- } \\
\text { 2004) }\end{array}$ & $\begin{array}{l}\text { During the later stage of the } \\
\text { merger (after 2004/2005 to } \\
\text { present) }\end{array}$ \\
\hline $\begin{array}{l}\text { Management } \\
\text { system of } \\
\text { the whole } \\
\text { group }\end{array}$ & $\begin{array}{l}\text { "Centralized management } \\
\text { with comprehensive } \\
\text { integration" in the iron } \\
\text { and steel business, } \\
\text { coupled with "appropr- } \\
\text { iately decentralized" } \\
\text { management model in } \\
\text { other sector of business- } \\
\text { es, relying mainly on the } \\
\text { specialized management } \\
\text { of functional departments } \\
\text { in the group headquarters }\end{array}$ & $\begin{array}{l}\text { "Relatively } \\
\text { decentralized" } \\
\text { management } \\
\text { model applied } \\
\text { both in the iron } \\
\text { and steel } \\
\text { business and } \\
\text { diversified } \\
\text { businesses; widely } \\
\text { and } \\
\text { strongly spread } \\
\text { the advanced } \\
\text { management } \\
\text { practice of } \\
\text { Baoshan Iron \& } \\
\text { Steel Corporation } \\
\text { into } \\
\text { the acquired } \\
\text { old-style } \\
\text { enterprises }\end{array}$ & $\begin{array}{l}\text { "Consolidating" the iron and } \\
\text { steel business across the } \\
\text { group enterprises and } \\
\text { cultivating the backbone } \\
\text { subsidiaries in each six } \\
\text { business sectors to be } \\
\text { sub-group companies in the } \\
\text { development and operation of } \\
\text { each sector of businesses; } \\
\text { while employing "centralized } \\
\text { management with comprehe- } \\
\text { nsive integration" in the } \\
\text { consolidating iron and steel } \\
\text { business relatively flexible } \\
\text { business models and } \\
\text { organizational structures are } \\
\text { adopted to fit individual } \\
\text { situations of each business }\end{array}$ \\
\hline $\begin{array}{l}\text { Relationship } \\
\text { between the } \\
\text { parent } \\
\text { company } \\
\text { and its } \\
\text { major } \\
\text { subsidiaries }\end{array}$ & $\begin{array}{l}\text { The group headquarters } \\
\text { were in charge of } \\
\text { running both the } \\
\text { dominant and diversified } \\
\text { businesses. A few large } \\
\text { subsidiaries were said to } \\
\text { be second-order "invest- } \\
\text { ment centers," but poss- } \\
\text { essed only rights of } \\
\text { investment suggestions } \\
\text { and business operation } \\
\text { without investment deci- } \\
\text { sion-making autonomies }\end{array}$ & $\begin{array}{l}\text { The group } \\
\text { headquarters did } \\
\text { not directly } \\
\text { involve in } \\
\text { subsidiaries' } \\
\text { operation, but } \\
\text { guided them } \\
\text { with the } \\
\text { directions and } \\
\text { objectives of } \\
\text { operations, and } \\
\text { coordinated the } \\
\text { strategies of } \\
\text { subsidiaries which } \\
\text { had such a high } \\
\text { level of autonomy } \\
\text { as to develop } \\
\text { mutually overlaid } \\
\text { businesses, } \\
\text { producing } \\
\text { dysfunctional } \\
\text { internal } \\
\text { competition }\end{array}$ & $\begin{array}{l}\text { The Group Corporation and its } \\
\text { owned or majority-share-held } \\
\text { subsidiaries (especially } \\
\text { Baoshan Iron \& Steel Co.) } \\
\text { are evolving as different } \\
\text { layered business entities } \\
\text { separated from each other in } \\
\text { both functions and institu- } \\
\text { tional setups. While the } \\
\text { Group Corporation adjusts } \\
\text { itself to act as pure holding } \\
\text { company, focusing on form- } \\
\text { ulating the grand strategy of } \\
\text { the whole group and cultiva- } \\
\text { ting the major subsidiaries } \\
\text { which are chosen as second- } \\
\text { level parenting companies } \\
\text { leading their affiliated } \\
\text { subsidiaries and business } \\
\text { units to develop and compete } \\
\text { in specific industrial fields, } \\
\text { thus forming some hetero- } \\
\text { geneous sub-groups within } \\
\text { the portfolio of Baosteel } \\
\text { Group }\end{array}$ \\
\hline
\end{tabular}


in the traditional hierarchy. There may be heterogeneity between a system and its subsystems. In our case, Baosteel demonstrates its unique allocation of functions and authorities among several organizational levels.

As to the operations management system of Baosteel's iron and steel business, vertical specialization emerges. The operational headquarters assume the comprehensive integrated supportive functions while the field units specialize in production. Correspondingly, the functions and duties related to supportive operations are concentrated at the headquarters while the worksite managers are empowered to make autonomous decisions on production.

Similar vertical specialization appears in Baosteel's strategic management system. Freeing itself from business operation and management, Baosteel Group Corporation does not interfere in the operation of any specific business, but rather focuses its energies on grand strategy and portfolio management of the group's diversified businesses, while subsidiaries in the same or related business sectors or industries are merged into consolidated sub-group companies, which are fully authorized to make strategic decisions in their designated sectors.

The common features of both operation and strategic management in Baosteel can be reflected by a simple phrase-decentralization of authority and concentration of business or duty, which is in sharp contrast to that of the traditional hierarchy characterized by centralization of authority and de-concentration of duty or business. Thus, it is reasonable to identify Baosteel as a heterarchical organization.

The two echelons of heterarchical models emerging in Baosteel can be identified through an inductive analysis on its experiences in both operations management and strategic management, as shown in Table 3. The table indicates that Baosteel Group Corporation as a parent company is functionally and organizationally differentiated from its subordinate companies in each sector or sub-group of business, and field units are also and further differentiate from their upper-level business entities as operating center of each business. The functional and organizational differences between different layers lead to the emergence of heterogeneity throughout Baosteel group.

\section{Discussion}

\subsection{Vertical Networked Structure under Layered Management}

Networked form of organizations as the "handshake" between market and hierarchy (Larsson, 1993) only presents a horizontally specialized business relationships between intra- or inter-organizational actors involved in economic exchanges. If we turn our attention to the vertical specialization (Simon, 1997) of multi-level actors, then organizations with the decentralization of authority and 
concentration of duty or business activity would be found to have a unique structure toward heterarchy which differs from the rigid hierarchy sharply, just as Baosteel.

Table 3 Identification and Comparison between Two Organizational Models

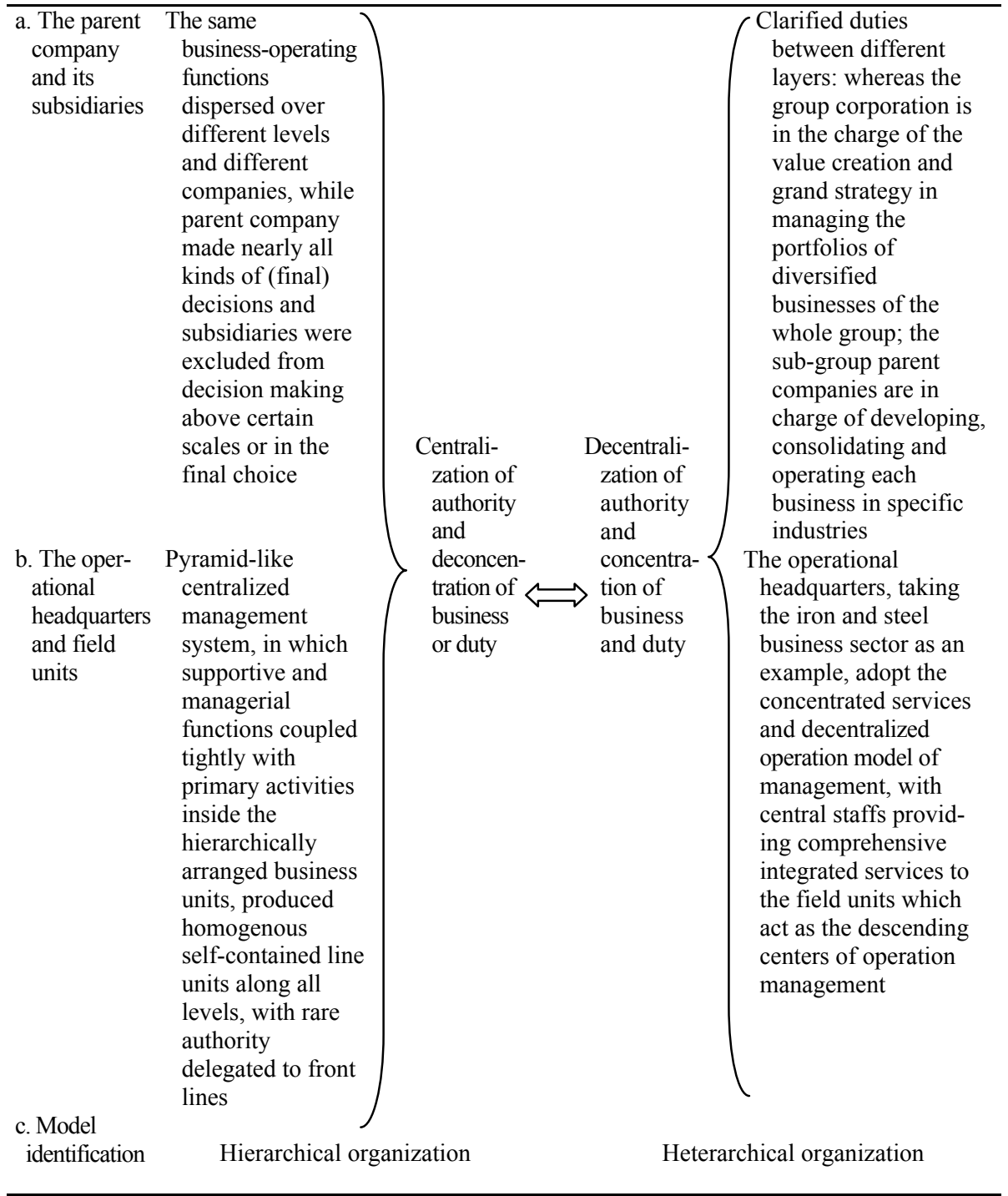

In the hierarchical management model adopted by China's pre-reformed enterprise (see Fig. 1a, with more details described in the left column of Table 1 and 3), every management layerllevel takes up almost the same activities with 
higher levels. Along the chain of command, the duty of a higher level are decomposed into smaller and smaller parts of similar duties downward till the bottom level. Following the simple linear logic, actor at every level (except the highest level) of the organization is homogenous without vertical specialization in its duty. In contrast, as in Baosteel's layered management system (see Fig. 1b, with more details in the right column of Table 1 and 3), the managerial duty across these layers $\backslash$ levels is not simply divided by quantity or volume (such as the amount of capitals invested or the volume of materials purchased), but by the quality or nature (the content or category of a decision, i.e., such as whether to invest in an industry rather than how much capital to invest). Thus, each level or layer in the managerial chain takes all the responsibilities belonging to the same kind, namely, the duty of the same quality concentrate on the specific layer. Therefore, the actors across layers become heterogeneous in terms of responsible business activities.

High level:

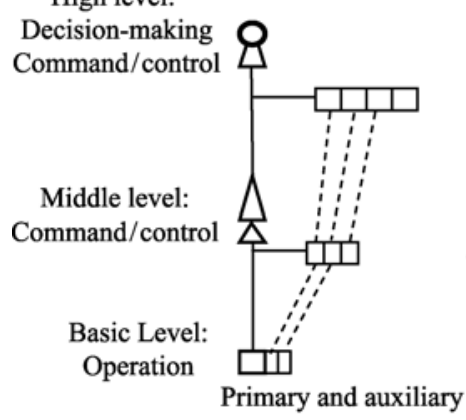

(a) Hierarchical Organizations

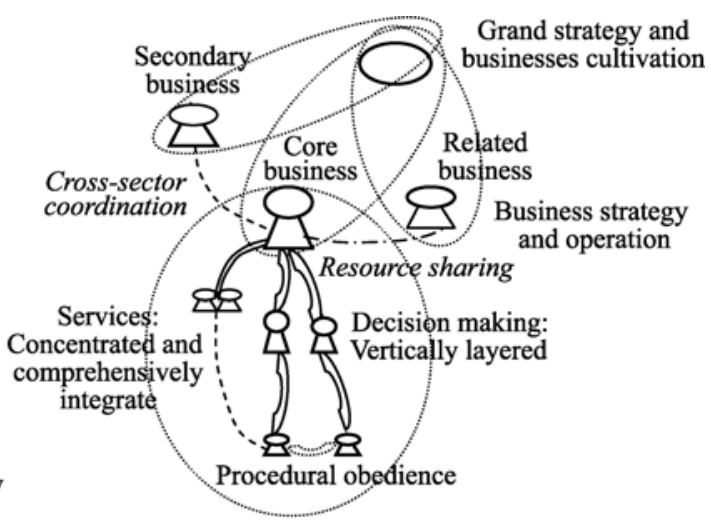

(b) Heterarchical Organizations

Fig. 1 Horizontal and Vertical Relations in Hierarchy and Heterarchy

In the operations management with descended center on the grass line, Baosteel specifies the different-in-nature duties along the 4-layered managerial chain to ensure the smooth functions of the nonhierarchical system. That is, worksite managers, as commanders and overall operation managers, are empowered to act autonomously, with few intervention from the higher levels; whereas workshop managers above them are required to manage operations indirectly, mainly through forecasting, getting a broad picture of operations in the workshop supervised, and setting up backing system for his/her subordinates; branch-factory managers are supposed to behave as a good leader in the branch, playing such supportive functions as cultivating subordinate managers, 
improving production system, and grasping information on advanced manufacturing technologies; and furthermore, staffs in the headquarters' various departments are turned to supply high-quality services, to act as wise consultants basing on survey and research, to organize forces for implementing strategies, to coordinate related functions, and to monitor and inspect in its professional field. This skeleton reflects the non-hierarchical relationship between the operational headquarters and grass-root field units.

As to Baosteel's system of strategic management, we see a similar picture. After the adoption of the layered management model, two-level subsystem emerges in the group management. The first level is Baosteel Group Co. that has adjusted itself to a pure holding company and starts to think and act for the whole group's overall and long-term benefits. The second level is a horizontal network made up of Baoshan Iron \& Steel Co. and other wholly- or majority-owned backbone subsidiaries, which as the second-level investment centers are empowered to make a wide range of decisions related to the industry development and business operation in their own domains. In this way, the backbone subsidiaries in the major business sectors become autonomous actors, gaining authority in making decisions related to the growth and competition in each designated industry.

In brief, through dividing the managerial duties based on the quality of decisions rather than quantity, Baosteel has converted the traditional hierarchical model to a heterarchical one in the systems of operation and strategic management. We therefore induce that:

Proposition 1 If managerial duties between levels/layers are divided on the basis of qualitative difference in decisions (rather then basing on quantitative criteria), then the organizational structure is more heterarchy-like and less hierarchy-like.

\subsection{Decentralization of Authority}

In hierarchical organizations, managers at all levels are involved in the same type of activities with major differences merely in scale of duties. Along the hierarchical chain, therefore, the duties of a higher level manager are decomposed into smaller scale of similar duties downward until to the bottom level. This means that the responsibilities of lower levels within a hierarchy can be simply summed up to get a whole picture of the higher-levels'. With this simple logic of reduction, each actor at all levels (except the highest level) in the organization is homogenous without "vertical specialization" in his/her functions. Due to this homogeneity, top managers (as the brain of a firm) always hold absolute authority in making decisions for the whole organization, while the 
middle and lower level actors with pieces of duties may only act as command-followers to implement the decisions made by the top mangers.

In comparison, in the heterarchical organizations, each actor at different managerial levels has corresponding decision-making authority over his her own responsible activities, behaving exactly as an active "agent" defined in the complexity science. Take Baosteel's operations management model as an example. In its iron and steel business, the compound functional departments in the operational headquarters are designated to provide comprehensively integrated supporting services for the field units, while worksite managers of field units focus their attention on the primary value-adding activities, i.e., production. The full decision-making authority over production is consequentially devolved down to worksite managers who are vividly called "quasi-plant-managers."

Connecting this observation on the lower system of operations management with that on the upper system of strategic management, we find that, although Baosteel appears having several managerial levels (thus are not flattened in shape), it shows a distinct organizational structure toward heterarchy. The whole group company, covering Baosteel Group Corporation, Baoshan Iron \& Steel Co. and other backbone subsidiaries (currently in the six business sectors), subsidiaries and independently-operated plants or factories, branch factories, workshops, and operating sections, is remarkably converted into a heterarchy that allocates autonomous decision makers with distinct agencies in making their strategic or operational decisions. With active actors cultivated gradually-That is, firstly in the system of operation management, and latterly or recently in the system of strategic management, Baosteel evolves from hierarchy into heterarchy in both the lower and upper echelon of administrative organization.

Through summarizing the experiences of Baosteel and by using the language in social network analysis which refers to that hierarchy as a kind of highly centralized network governed via central authority while market as a disperse network composed of a variety of isolated actors (Powell, 1990), we sum up the following two characteristics of heterarchy appeared in Baosteel. Firstly, the nodes in a heterarchy are heterogeneous actors with agency in making autonomous decisions divided in accordance with qualitative criteria. Secondly, in a heterarchy, there are multi-dimensional relations between actors across levels within or beyond one managerial system, compared with hierarchy in which actors are command-followers and subject to only "parent-child" or "supervisor-subordinate" pattern of relationships. Given the above comparison between hierarchy and heterarchy, we propose proposition 2 as follows:

Proposition 2 Different from hierarchy, in which only the top managers play the sole role of decision-making (thus acting as the single center of the organization) while other actors at the middle or lower levels are passive 
implementers, following commands from the top, the managers at diverse levels within a heterarchical organization are heterogeneous autonomous agents, no matter how lower their positions are in the managerial chain of the organization.

More importantly, what higher-level managers in Baosteel delegate downward is authority and corresponding responsibility but not the accountability. For instance, while the branch-factory and further workshop-level managers authorize worksite managers to behave as commanders at the frontline, it is the higher-level managers, including workshop and branch-factory managers who absolutely take accountability for worksite managers' decisions. In this dual relationship of responsibility downward but of accountability upward, cultivating subordinates' abilities in making right decisions has become an important task of higher-level managers in Baosteel. Only equipping heterogeneous actors with necessary agency (including the attitudes and abilities) in making their designated autonomous decisions, can the empowerment on active actors brings about the expected results. Thus we conclude the following:

Proposition 3 Seeing from the vertical relationships among diverse levels, to maintain a heterarchical organizational structure, high level managers should not only make their "reserved" decisions on their own, but also learn to delegate appropriate decisions distinct from those reserved and to cultivate their subordinates' abilities in making right decisions which are not suitable to be made at higher levels.

\subsection{The Formation and Applicability of Heterarchical Organization}

As described in the case study, we find that Baosteel exhibits a heterarchical structure in which it empowers its flagship subsidiaries, in condition of business consolidation, to govern other subsidiaries which operate in similar sectors of business or industry, as far as the strategic management system is concerned; meanwhile, in the operations management system, the authorities of sub-group companies over production are devolved downward to the front-line managers while various supporting functions are concentrated in the integrated compound departments at the operational headquarters. The paradoxical directions of decentralization of authority and consolidation $\backslash$ concentration of business or duty drive the formerly hierarchical organization mutating toward heterarchy. Based on these discussions above, we propose the following:

Proposition 4 Combining decentralization of authority and concentration of business (or function) together is the foundation to form a heterarchy.

Meanwhile, different from what Birkinshaw and Morrison's (1995) conclusion that heterarchy is only suitable to the parent-subsidiary level in geographically 
scattered MNCs, we find that heterarchy is applicable in both the upper system of strategic management and the lower system of operations management of large-sized enterprises located mostly domestically, as demonstrated in the Baosteel's case. We thus induce that:

Proposition 5 Given a certain level of complexity in business systems, the model of heterarchy is applicable in any (sub)system of administrative organization, no matter in the operations management of a specific business sector or in the strategic management of the whole business group.

\section{Conclusion}

In this article, we argue that hierarchical organizations, not necessarily being replaced by the networked form as supposed in extant literature, can reenergize themselves through some mutations toward heterarchical form to survive and thrive in current competitive, dynamic environments. Contrary to much research which focused on horizontal specialization (disintegration of "supply chain") between or within organizations, we address the vertical specialization (reconfiguration of "managerial chain") between different organizational levels. And we find that it is the change of vertical relations in "administrative organization" (Simon, 1997) that pushes hierarchy to convert into heterarchy. The qualitative case study on Baosteel's managerial systems helps us to distinguish heterarchy from the previous hierarchical form and to discover that the combination of decentralization of authority and concentration of business or duty is the key driving force behind the evolution of hierarchy toward heterarchy. Meanwhile, the practices of Baosteel show that heterarchy is applicable in any components of managerial systems, including those of operation and strategic management, not limited to the global parent-subsidiary relationship in MNCs as proposed by Birkinshaw and Morrison (1995).

As the case study on Baosteel shows, enterprises with several levels/layers of organizational actors along the managerial chain can deviate from hierarchy to a kind of heterarchy for getting better fitness in the competitive, dynamic business environments and remain the non-substituted status as a distinctive form of organization.

Heterarchy, or a pattern of mutated hierarchy, presents a "handshake" between the traditional strictly-defined hierarchy and the network which is generally regarded as a hybrid composite of business units or independent firms as nodes and their repeating transactions as ties. And by adopting the approach of social network analysis focusing on nodes and ties, we examine the structural characteristics of heterarchical organizations composed of autonomous actors involved in operational or strategic decision making and linked together through the chain of responsibility (rather than the chain of command). Furthermore, we 
analyze the evolutionary path of heterarchy, which is a paradoxical combination of decentralization of authority and concentration of business activities.

We theorize our main findings with five propositions. The basic conclusion is that, in governing the complex business organizations in the competitive, dynamic environments, a heterarchical model of administrative organization with the organizing principles alien to those of traditional hierarchy can enhance firms' stability and efficiency, on the one hand, via the still-in-shape hierarchical or layered managerial systems, and by the virtue of self-adaptation of heterogeneous actors widely dispersed across levels/layers of managerial systems; while the heterarchical form of organization can, on the other hand, improve the flexibility and overall effectiveness of the whole company.

The study may have two practical implications. Firstly, organizations can prosper in a complex and turbulent environment by adopting a heterarchical form, in which activities are concentrated while authority is decentralized and placed on actors who are in charge of those activities. Those practices will enhance organizational efficiency and effectiveness simultaneously just as Baosteel. Secondly, for most managers working under the threat of downsizing and flattening, the evolution toward heterarchy sheds new light on their careers, which provides opportunities to accumulate knowledge and experiences in the broader fields, and improve their abilities to make decisions independently.

Although this research is a single longitudinal case study on Baosteel, it contributes to the development of organization theory and promotes future empirical research on the characteristics and evolution of heterarchy. Further work may be done in two fields. First, to generalize the findings, quantitative studies with large samples are desired to verify the propositions induced in this article. Second, as found in present case study, the autonomous actors in heterarchy are active in making operational or strategic decisions as agents, thus the underlying agency and its effects need to be explored further from an interdisciplinary research across organization theory and complex science.

Acknowledgements This work is supported by the National Natural Science Foundation of China (No.70571082), the project of Basic Research on Chinese Style of Management co-supervised by Development Research Center of the State Council, China Enterprise Confederation and Tsinghua University, and the Humanities and Social Science Program of Ministry of Education of People's Republic of China (No. 08JA630086). Thanks also go to doctoral students Yang Yang and Zhen Zhen for their strong contribution to the revision of the original paper.

\section{References}

Blau P M, Meyer M W (1987). Bureaucracy in Modern Society (3rd ed.). New York: McGraw-Hill Inc. 
Birkinshaw J M, Morrison A J (1995). Configurations of strategy and structure in subsidiaries of multinational corporations. Journal of International Business Studies, 26(4): 729-753

Chandler A D, Daems H (1980). Managerial Hierarchies: Comparative Perspectives on the Rise of the Modern Industrial Enterprise. Cambridge: Harvard University Press

Coase R H (1952). The nature of the firm. In: Stigler G J, Boulding K E (ed.), Readings in Price Theory. Home-wood, IL: Irwin

Cohen M D (2007). Administrative behavior: Laying the foundations for Cyert and March. Organization Science, 18(3): 503-506

Drucker P F (1973). Management: Tasks, Responsibilities and Practice. New York: Harper and Row Publishers, Inc.

Eisenhardt K M, Graebner M E (2007). Theory building from cases: Opportunities and challenges. Academy of Management Journal, 50(1): 25-32

Ghoshal S, Gratton L (2002). Integrating the enterprise. MIT Sloan Management Review, 44(1): 31-38

Hedlund G (1986). The hypermodern MNC: A heterarchy. Human Resource Management, 25(1): 9-26

Heckscher C C (2007). The Collaborative Enterprise-Managing Speed and Complexity in Knowledge-Based Businesses. New Haven: Yale University Press

Jacobides M G (2007). The inherent limits of organizational structure and the unfulfilled role of hierarchy: Lessons from a near-war. Organization Science, 18(3): 455-477

Jaques E (1990). In praise of hierarchy. Harvard Business Review, 68: 127-133

Kast F E, Rosenzweig J E (1979). Organization and Management: A Systems and Contingency Approach. New York: McGraw-Hill

Larsson R (1993). The handshake between invisible and visible hands. International Studies of Management and Organization, 23(1): 87-107

Laurent A (1978). Managerial subordinacy: A neglected aspect of organizational hierarchies. Academy of management review, 3(2): 220-230

Leavitt H J (2003). Why hierarchies thrive. Harvard Business Review, 81(3): 96-102

McCulloch W S (1965). A heterarchy of values determined by the topology of nervous nets. In: McCulloch W S (ed.), the Embodiment to Mind. Cambridge, MA: MIT Press

Milgram S (1974). Obedience to Authority. London: Tavi-stock Publications

Powell W W (1990). Neither market nor hierarchy: Network forms of organization. In: Staw B M, Cummings L L (eds.), Research in Organizational Behavior, 12. Greenwich, CT: JAI, 295-336

Radner R (1992). Hierarchy: The economics of managing. Journal of Economic Literature, 30(3): 1382-1415

Simon H A (1962). The architecture of complexity. Proceedings of the American Philosophical Society, 106(6): 467-482

Simon H A (1997). Administrative Behavior: A Study of Decision-Making Processes in Administrative Organizations ( $4^{\text {th }}$ ed.). New York: The Free Press

Weber M (1978). Economy and Society. Berkley: University of California Press

Williamson O E (1991). Comparative economic organization: The analysis of discrete structural alternatives. Administrative Science Quarterly, 36(2): 269-296

Williamson O E (1996). The Mechanisms of Governance. Oxford: Oxford University Press

Yin R T (2004). Case Study Research: Design and Methods ( $3^{\text {rd }}$ ed.). Thousand Oaks, CA: Sage

国务院发展研究中心, 中国企业联合会, 清华大学 (Development Research Center of the State Council, China Enterprise Confederation, Tsinghua University) (2007). 中国式企业 
管理成功之道研究——宝钢集团有限公司 (Ways to Success with Chinese Style of Management). 北京，内部交流资料, 213

郭建光, 郭亚军, 易平涛, 黄立毅 (Guo Jianguang, Guo Yajun, Yi Pingtao, Huang Liyi) (2006). 解析宝钢的体制变革 (An Explanation on Baosteel's Reforms of Managerial Systems). 企业管理, (4): 62-66

宝钢集团有限公司 (Baosteel Group Corporation) (2007). 以不断的管理创新赢得持续竞 争优势 (Gaining long-lasting competitive advantages through continuous managerial innovation). 冶金管理, (6): 13-15 